\title{
Analisis Banjir Di Kawasan Jondul Rawang Kota Padang
}

\section{Food Analysis In The Jondul Rawang Area of Padang City}

\author{
Beno Putra Susanto, Dyen Triana Putri, Zahrul Umar \& Aguskamar \\ Jurusan Teknik Sipil Politeknik Negeri Padang Kampus Limau Manis Padang \\ Telp. 0751-72590 Fax. 0751-72576 \\ Email: beno.putrasusanto@yahoo.co.id, dyen.trianaputri@yahoo.com
}

\begin{abstract}
Flood has been an endless disaster for human being all over the world since the past, nowadays and in future. Water flood may be affected by nature or human activities or even by both nature and human. Almost all region in Indonesia facing the flood problem with various scale and time.Jondul Rawang one place located in south side of Padang city for example is always suffer with water flood. This study is an analysis of flood for Jondul Rawang, using EPA SWMM 5.1 software with simulation method. The simulation result will show location of points on drainage system which start to offer flowincluding the time and duration. Calculation is made based on collected data, hydrology and hydraulyc analysis. The data should cover primary and secondary drainage system then come out with design flood and hydraulyc analysis to check the capacity of drainage.Calculation of rainfall for repeat period using probability method Chi-Kuadratand Smirnov-Kolmogorof will obtain Log Normal Method for rainfall 251,62 $\mathrm{mm}$. To calculate water debit inside drainage for 5 years period flood exist channel 1-2, 3-4, 5-6, and 8-9 with respective overflow 4,5 $\mathrm{m}^{3} / \mathrm{sec}, 6,53 \mathrm{~m}^{3} / \mathrm{sec}, 6,36 \mathrm{~m}^{3} / \mathrm{sec}$, and $6,50 \mathrm{~m}^{3} / \mathrm{sec}$. While capacity of respective existing drainage are lower such as: $4,47 \mathrm{~m}^{3} / \mathrm{sec}, 5,48 \mathrm{~m}^{3} / \mathrm{sec}, 2,96 \mathrm{~m}^{3} / \mathrm{sec}$, and 1,82 $\mathrm{m}^{3} / \mathrm{sec}$. Solution to be taken place to resolve the flood problem for Jondul Rawang are Enlarge the drainage size, build retention pond and build infiltration pond.
\end{abstract}

Keywords : Banjir, Intensitas Hujan, Simulasi, Software EPA SWMM 5.1

\section{PENDAHULUAN}

Banjir atau terjadinya genangan di suatu kawasan pemukiman atau perkotaan masih banyak terjadi di berbagai kota di Indonesia. Genangan tidak hanya dialami oleh kawasan perkotaan yang terletak di dataran rendah saja, bahkan dialami oleh kawasan yang terletak di dataran tinggi. Banjir atau genangan di suatu kawasan terjadi apabila sistem yang berfungsi untuk menampung genangan itu tidak mampu menampung debit yang mengalir, hal ini akibat dari tiga kemungkinan yang terjadi yaitu : kapasitas sistem yang menurun, debit aliran air yang meningkat, atau kombinasi dari keduaduanya. Selain sistem drainase yang tidak berfungsi secara optimal, perubahan tata guna lahan juga menjadi salah satu penyebab terjadinya banjir. Perubahan tata guna lahan dari lahan pertanian menjadi lahan pemukiman mengakibatkan kurangnya serapan air hujan, berubahnya jumlah dan dimensi saluran drainase yang ada sehingga proses penyerapan air ke dalam tanah berkurang dan banjir meningkat (Ihsan $M$, dan Setiawan $B I$, 2014: Rohmat , D 2009). Bencana banjir sudah menjadi langganan setiap tahunnya di Sumatera Barat, khususnya Kota Padang. Salah satu daerah yang mengalami banjir adalah komplek Jondul Rawang kecamatan Padang selatan. Penyebab terjadinya banjir di daerah tersebut adalah akibat tingginya intensitas curah hujan, sistem drainase yang tidak berfungsi dengan baik dan kurangnya kepedulian masyarakat terhadap lingkungan serta pemerintah yang bergerak lambat mengatasi masalah banjir tersebut.

\section{METODOLOGI}

\section{Lokasi Penelitian}

Penelitian ini dilakukan di Kawasan Jondul Rawang, Kota Padang 
dengan menganalisis banjir yang terjadi dikawasan tersebut.

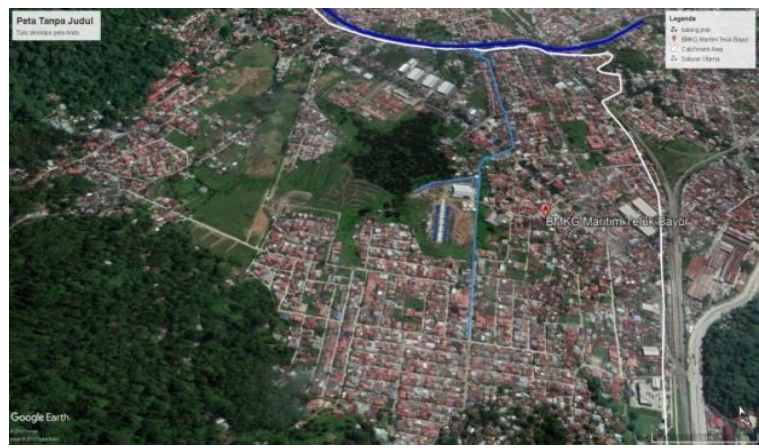

Gambar 1. Lokasi penelitian

\section{Analisa Hidrologi}

Time series curah hujan merupakan input pada SWMM. Analisis frekuensi dilakukan dengan menggunakan teori probability distribution, yaitu Distribusi Normal, Distribusi Log Normal, Distribusi Log Pearson III dan Distribusi Gumbel. Untuk penentuan jenis distribusi yang digunakan dilakukan uji Parameter Statistik dan uji kecocokan dengan metode Chi Kuadrat dan Smirnov-Kolmogorof. Dalam penelitian ini perhitungan analisa curah hujan menggunakan metode Log Normal. Setelah distribusi ditetapkan, nilai curah hujan rencana dapat dihitung dengan kala ulang 5 tahun. Dari nilai curah hujan rencana yang didapat dilakukan pembuatan pola distribusi hujan jam-jaman dengan metoda Altenating Block Method. Curah hujan jam-jaman ini merupakan input rain gage pada EPA SWMM.

\section{Tata Guna Lahan}

Tata guna lahan merupakan salah satu parameter yang merupakan input ke pemodelan EPA SWMM 5.1 melalui nilai $\%$ pervious area dan \% impervious area. Pervious area merupakan area yang memungkinkan terjadinya infiltrasi pada suatu subcathment. Sedangkan daerah yang tidak lolos air (tidak terjadi infiltrasi) disebut impervious area. Besarnya jumlah impervious area akan mempengaruhi debit limpasan yang terjadi pada tiap subcathment. Semakin besar \% impervious area akan semakin besar jumlah debit limpasan yang terjadi.

\section{EPA SWMM 5.1}

Storm Water Management Model (SWMM) merupakan model simulasi hujan- aliran (rainfall-runoff) yang digunakan untuk simulasi kuantitas maupun kualitas limpasan permukaan dari daerah perkotaan. (Manual SWMM 5.1, 2015). Objek yang digunakan dalam penelitian software ini yaitu rain gage, subcatchment, junction, saluran (Conduit) dan storage unit. Rain gage meliputi data intensitas curah hujan, interval waktu pengamatan,dan sumber data hujan berupa time series. Subcatchment meliputi menentukan outlet subcatchment, menentukan tataguna lahan, menentukan pervious dan impervious subarea, menentukan slope atau kemiringan subcatchment, menentukan lebar Subcatchment, menentukan bilangan manning untuk aliran permukaan, menentukan persentase impervious subarea, menentukan depression storage daerah pervious dan impervious, menentukan persentase daerah impervious tanpa depression storage.

Junction adalah titik sistem drainase dimana saluran-saluran bergabung. Datayang dibutuhkan yaitu elevasi ketinggian, kedalaman maksimum, area tampungan ketika terjadi banji (jika ada), aliran dari luar system drainase (jika ada). Pada saluran (Conduit), parameter yang akan digunakan yaitu Shape (bentuk saluran), max depth (kedalaman), length (panjang saluran), roughness (koefisien kekasaran saluran). Storage unit adalah titik pada system drainase yang merupakan volume penyimpanan. Parameter storage unit meliputi : elevasi atau ketinggian, kedalaman maksimum, kedalaman air awal (initial depth), evaporasi potensial, parameter rembesen (jika ada), data external inflow (jika ada).

Penelitian ini dilakukan dengan beberapa tahapan. Pertama, pengumpulan data berupa data primer dan data sekunder. Pada penelitian yang dilakukan kali ini 
lebih banyak menggunakan dan dipengaruhi oleh data sekunder (data curah hujan, data eksisting saluran, data topografi saluran, data tata guna lahan). Pengumpulan data curah hujan dari stasiun pengamatan hujan BMKG Maritim Teluk Bayur diperoleh dari kantor BMKG Jondul Rawang. Data Eksisting Saluran dan data Topografi saluran di dapat dari Dinas PSDA Provinsi Sumatera Barat. Data Tata Guna Lahan dan Data Pola Aliran di peroleh dari Google Earth. Langkah selanjutnya menghitung curah hujan rencana menggunakan metode Log Normal, menghitung hyetograph hujan rencana dengan menggunakan metode Alternating Block Method (ABM). Kemudian Simulasi Program EPA SWMM 5.1 dengan menggunakan data yang telah di analisa. Hasil simulasi program berupa debit limpasan yan di tampung oleh saluran serta lokasi titik-titik banjir yag terjadi disepanjang saluran drainase. Pada akhirnya kita dapat mengetahui solusi pengendalian banjir berdasarkan analisis terhadap simulasi yang telah dilakukan.

\section{HASIL DAN PEMBAHASAN}

\section{Analisis Curah Hujan Rencana}

Perhitungan curah hujan rencana menggunakan data hujan maksimum tahunan menggunakan metode Log Normal. Untuk hasil perhitungan dapat dilihat pada tabel dibawah ini.

Tabel 1. rekapitulasi perhitungan curah hujan rencana

\begin{tabular}{|c|c|c|}
\hline No & $\begin{array}{c}\text { Periode } \\
\text { ulang hujan }\end{array}$ & $\begin{array}{c}\text { Curah hujan } \\
\text { rencana }(\mathrm{mm})\end{array}$ \\
\hline 1 & 2 & 213.18 \\
\hline 2 & 5 & 251.62 \\
\hline 3 & 10 & 274.44 \\
\hline
\end{tabular}

\section{Perhitungan Intensitas Hujan}

Setelah didapatkan nilai curah hujan, selanjutnya perhitungan intensitas hujan menggunakan metode Mononobe dengan periode ulang hujan 5 tahun. Hasil dari perhitungan intensitas hujan berupa kurva IDF yang nantinya akan digunakan dalam penyusunan Hyetograph hujan rencana dengan Alternating Block Method (ABM). Untuk hasil perhitungan intensitas hujan dengan menggunakan rumus Mononobe dilampirkan pada tabel dibawah ini.

Tabel 2.Perhitungan intensitas hujan

\begin{tabular}{|c|c|c|}
\hline \multicolumn{2}{|c|}{ Durasi } & $\begin{array}{c}\text { Intensitas } \\
\text { Hujan Perioda } \\
\text { Ulang 5 th }\end{array}$ \\
\hline Menit & (Jam) & 251,62 \\
\hline 30 & 0.5 & 138.471 \\
\hline 60 & 1.0 & 87.231 \\
\hline 90 & 1.5 & 54.952 \\
\hline 120 & 2.0 & 41.936 \\
\hline 150 & 2.5 & 34.618 \\
\hline 180 & 3.0 & 29.833 \\
\hline
\end{tabular}

\section{Perhitungan Hyetograph Hujan Rencana}

Untuk perhitungan pola distribusi hujan jam-jaman dengan metode Alternating Block Method (ABM) menggunakan hasil perhitungan dari intensitas hujan pada tabel 2 dengan durasi kejadian hujan yang diambil selama 3 jam.

Tabel 3. Hasil hyetograph hujan rencana periode ulang 5 tahun

\begin{tabular}{|c|c|c|}
\hline \multirow{2}{*}{ Durasi (t) } & \multicolumn{2}{|c|}{ Hyetograph } \\
\hline Jam & $\%$ & $\mathrm{~mm}$ \\
\hline 1.0 & 18.022 & 45.346 \\
\hline 2.0 & 69.336 & 174.462 \\
\hline 3.0 & 12.642 & 31.809 \\
\hline Total & 100 & 251.6184 \\
\hline
\end{tabular}

\section{Hyetograph Hujan}

Rencana

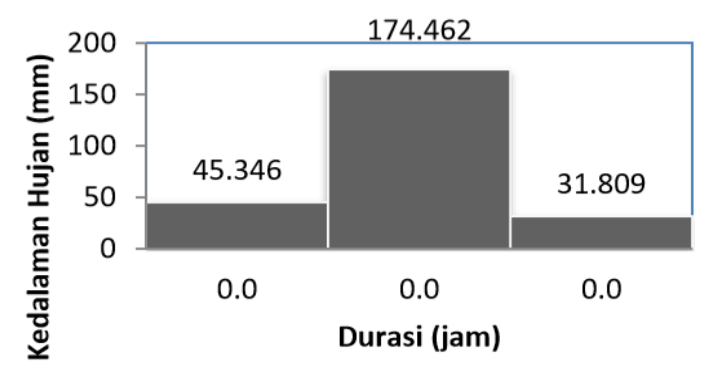

Gambar 2. Hyetograph hujan rencana periode ulang hujan 5 tahun

\section{Debit Limpasan}


Hasil simulasi debit limpasan pada setiap subcatchment akibat hujan periode ulang 5 tahun dapat dilihat pada tabel berikut :

Tabel 4. Debit Limpasan pada periode ulang 5 Tahun

\begin{tabular}{|c|c|c|c|}
\hline DTA & Luas & Impervious(\%) & $\begin{array}{c}\begin{array}{c}\text { Debit } \\
\text { Puncak } \\
(\mathrm{m} 3 / \text { detik) }\end{array} \\
251.62\end{array}$ \\
\hline S1 & 37 & 0.34 & 6.03 \\
\hline $\mathrm{S} 2$ & 6.44 & 0.66 & 1.62 \\
\hline S3 & 5.31 & 0.63 & 1.23 \\
\hline S4 & 4.52 & 0.42 & 1.57 \\
\hline S5 & 1.48 & 0.15 & 0.43 \\
\hline S6 & 0.63 & 0.70 & 0.29 \\
\hline S7 & 0.31 & 0.70 & 0.15 \\
\hline S8 & 0.25 & 0.70 & 0.12 \\
\hline S9 & 6 & 0.53 & 2.08 \\
\hline S10 & 4.1 & 0.52 & 1.41 \\
\hline $\mathrm{S} 11$ & 2.22 & 0.56 & 0.88 \\
\hline $\mathrm{S} 12$ & 2.4 & 0.70 & 1.11 \\
\hline S13 & 0.7 & 0.70 & 0.34 \\
\hline S14 & 0.61 & 0.70 & 0.29 \\
\hline S15 & 0.84 & 0.70 & 0.4 \\
\hline
\end{tabular}

Dari hasil tersebut dapat diketahui bahwa subcathment yang memiliki debit puncak limpasan maksimum terdapat pada subcathment yang memiliki luas terbesar yaitu subcathment 1. Selain luas area, \% impervious area juga memiliki pengaruh terhadap debit puncak limpasan yang dihasilkan.

\section{Titik-Titik Banjir}

Akibat Hujan Periode Ulang 5 tahun Berdasarkan hasil simulasi kita dapat mengetahui dimana lokasi titik-titik yang mengalami banjir, waktu terjadi banjir dan durasi banjir.

Tabel 5. Node flooding summary akibat hujan periode ulang 5 tahun

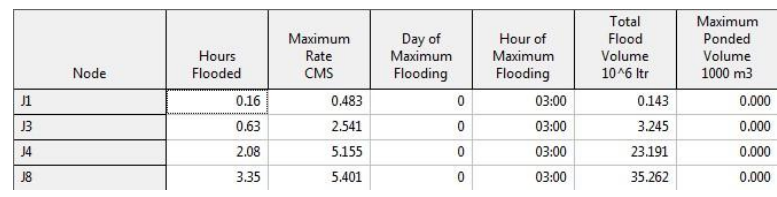

Dari tabel dapat diketahui bahwa terdapat 4 titik yang mengalami banjir atau over capacity, titik J8 merupakan titik yang paling lama mengalami banjir yaitu selama 3,35 jam. Sedangkan titik dengan volume banjir yang paling besar adalah titik J8. Selain mengetahui titik banjir, hasil simulasi juga dapat menampilkan grafik aliran yang terjadi pada saluran yang dapat dilihat pada gambar 3 .

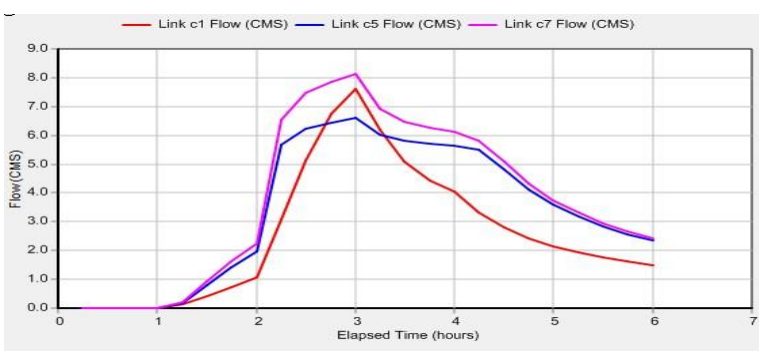

Gambar 3. Grafik aliran $\mathrm{C} 1, \mathrm{C} 5$ dan $\mathrm{C} 7$

Pada gambar diatas dapat dilihat puncak grafik di $\mathrm{C} 1$ dan $\mathrm{C} 7$ menggambarkan bahwa saluran mengalami banjir, sementara pada grafik C5 dapat menggambarkan puncak aliran terjadi pada jam ke 3 dan tidak terjadi banjir. Profil memanjang saluran dapat dilihat pada gambar 4 dan 5 .

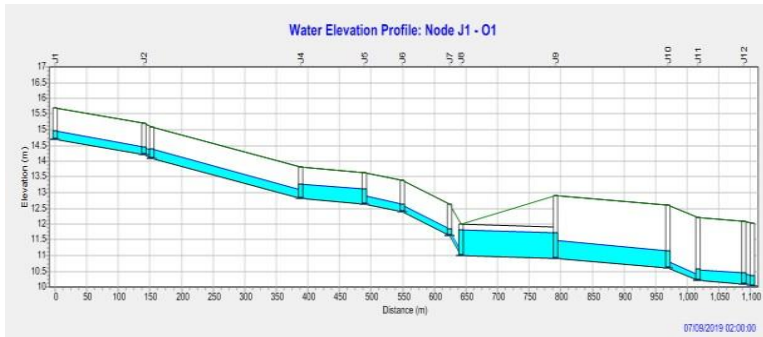

Gambar 4. Profil memanjang saluran akibat $R$ 5 tahun 2 jam setelah hujan

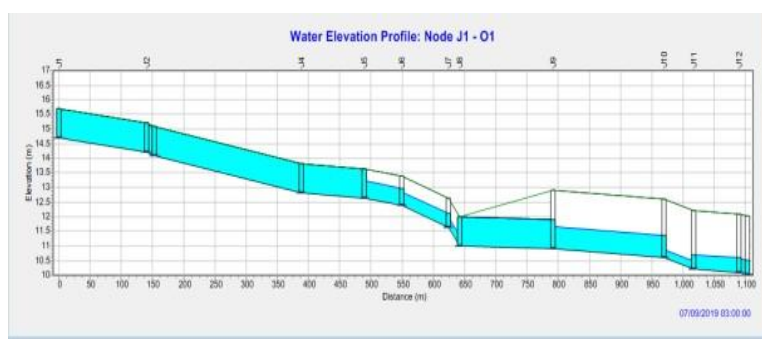

Gambar 5. Profil memanjang saluran akibat $\mathrm{R}$ 5 tahun 3 jam setelah hujan

Pada saat jam kedua belum ada saluran yang mengalami banjir tetapi pada saat jam ke-3 saluran J1, J3, J4, dan J8 sudah mengalami banjir. Hal tersebut terjadi karena pada saat jam kedua terjadi puncak hujan dan masih terjadi di lahan. Sementara 
pada saat jam ketiga air tersebut telah sampai disaluran yang menyebakan saluran mengalami debit maksimum. Dari hasil simulasi dengan menggunakan hujan periode ulang 5 tahun, saluran tidak menampung debit limpasan yang terjadi kerena masih terdapat saluran yang banjir atau over capacity. D. Perbandingan Debit Manual dan EPA SWMM 5.1

Menggunakan Periode Ulang 5 Tahun Debit manual dengan menggunakan metode Rasional Data saluran subcathment 1 :

$\mathrm{Rn}=241,618$

$\mathrm{A}=0,37 \mathrm{Km} 2$

$\mathrm{L}=0,35 \mathrm{Km}$

$\mathrm{S}=0,0006$

$\mathrm{C}=0,34$

Rumus Kirpich :

$$
\begin{aligned}
\mathrm{tc} & =\left[\frac{0,87 \times L^{2}}{1000 \times S}\right] \wedge 0.385 \\
\mathrm{tc} & =\left[\frac{0,87 \times 0,35^{2}}{1000 \times 0,0006}\right] \wedge 0.385 \\
\mathrm{tc} & =0,514 \\
I & =\frac{R 24}{24} \times\left(\frac{24}{t}\right)^{\frac{2}{3}} \\
I & =\frac{251,618}{24} \times\left(\frac{24}{0,514}\right)^{\frac{2}{3}} \\
I & =62,104 \mathrm{~mm} / \mathrm{jam} \\
Q & =0,278 \times \mathrm{C} . \mathrm{I} \cdot \mathrm{A} \\
Q & =0,278 \times 0,34 \times 62,104 \times 0,37 \\
Q & =2,149 \mathrm{~m}^{3 / \mathrm{det}}
\end{aligned}
$$

Jadi besarnya debit yang terdapat pada saluran subcatchment 1 adalah : 2,149 $\mathrm{m} 3 /$ det. Berikut tabel nilai perbandingan debit manual dan EPA SWMM 5.1

Tabel 6. nilai perbandingan debit manual dan EPA SWMM 5.1

\begin{tabular}{|c|c|}
\hline $\begin{array}{c}\text { Debit Manual } \\
(\mathrm{m} 3 / \text { det })\end{array}$ & $\begin{array}{c}\text { Debit EPA SWMM } \\
(\mathrm{m} 3 / \text { det })\end{array}$ \\
\hline 2,15 & 6,03 \\
\hline 0,69 & 1,62 \\
\hline 0,44 & 1,23 \\
\hline 0,76 & 1,57 \\
\hline 0,04 & 0,43 \\
\hline 0,12 & 0,29 \\
\hline 0,06 & 0,15 \\
\hline 0,06 & 0,12 \\
\hline 0,82 & 2,08 \\
\hline 0,01 & 1,41 \\
\hline 0,27 & 0,88 \\
\hline 0,60 & 1,11 \\
\hline 0,17 & 0,34 \\
\hline 0,15 & 0,29 \\
\hline 0,11 & 0,40 \\
\hline
\end{tabular}

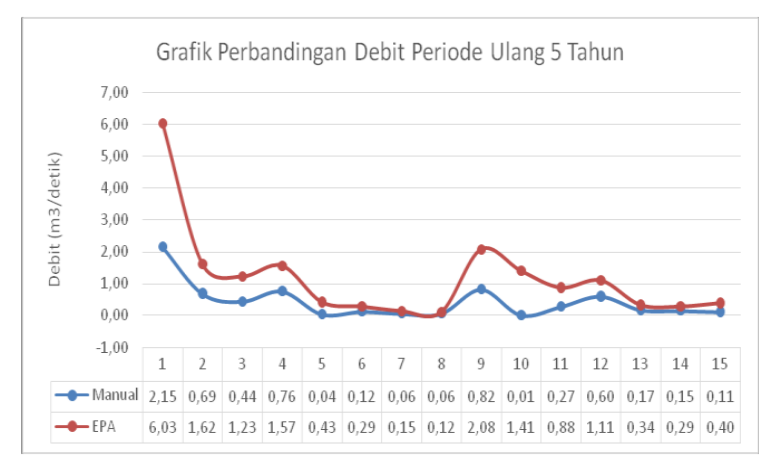

Gambar 6. Grafik Perbandingan debit

Debit Limpasan di Saluran Persamaan metode rasional tidak untuk menghitung debit dari tiap debit masukan kemudian dijumlahkan. Hal ini akan mengabaikan perbedaan waktu debit puncak pada masing-masing sub-area. Berikut adalah data saluran dan bentuk saluran drainase jondul rawang :

Tabel 7. Data Saluran Drainase Jondul Rawang

\begin{tabular}{|c|c|c|c|c|c|c|c|c|}
\hline Saluran & $\begin{array}{c}\mathrm{b} \\
(\mathrm{m})\end{array}$ & $\begin{array}{c}\mathrm{h} \\
(\mathrm{m})\end{array}$ & $\begin{array}{c}\mathrm{A} \\
\left(\mathrm{m}^{2}\right)\end{array}$ & $\begin{array}{c}\mathrm{P} \\
(\mathrm{m})\end{array}$ & $\begin{array}{c}\mathrm{R} \\
(\mathrm{m})\end{array}$ & $\mathrm{n}$ & $\mathrm{I}$ & $\begin{array}{c}\mathrm{V} \\
(\mathrm{m} / \mathrm{det})\end{array}$ \\
\hline $1-2$ & 2 & 1 & 2 & 4 & 0,5 & 0,017 & 0,004 & 2,24 \\
\hline $2-3$ & 2 & 1 & 2 & 4 & 0,5 & 0,017 & 0,008 & 3,25 \\
\hline $3-4$ & 2 & 1 & 2 & 4 & 0,5 & 0,017 & 0,005 & 2,74 \\
\hline $4-5$ & 2 & 1 & 2 & 4 & 0,5 & 0,017 & 0,002 & 1,48 \\
\hline $5-6$ & 3 & 1 & 3 & 5 & 0,6 & 0,017 & 0,004 & 2,80 \\
\hline $6-7$ & 3 & 1 & 3 & 5 & 0,6 & 0,017 & 0,010 & 4,13 \\
\hline $7-8$ & 3 & 1 & 3 & 5 & 0,6 & 0,017 & 0,036 & 7,89 \\
\hline $8-9$ & 2 & 1 & 2 & 4 & 0,5 & 0,017 & 0,001 & 0,91 \\
\hline $9-10$ & 2 & 2 & 4 & 6 & 0,7 & 0,017 & 0,002 & 1,91 \\
\hline $10-11$ & 4 & 2 & 8 & 8 & 1 & 0,017 & 0,008 & 5,37 \\
\hline $11-12$ & 4 & 2 & 8 & 8 & 1 & 0,017 & 0,001 & 2,19 \\
\hline $12-13$ & 2,4 & 2 & 4,8 & 6,4 & 0,75 & 0,017 & 0,007 & 4,10 \\
\hline
\end{tabular}

Data saluran $1-2$ :

$\mathrm{b}=2$ Meter $\mathrm{h}=$

1 Meter $\mathrm{A}=$

bxh

$$
\begin{aligned}
& =2 \times 1 \\
& =2 \text { Meter }^{2} \\
\mathrm{P} & =\mathrm{b}+2 \mathrm{~h} \\
& =2+2 \times 1 \\
& =4 \text { Meter } \\
& \mathrm{A} \quad \frac{2}{\mathrm{R}}=\frac{\mathrm{P}}{4}=0,5 \text { Meter } \\
\mathrm{V} & =1 / \mathrm{n} \cdot \mathrm{R}^{2 / 3} \cdot \mathrm{I}^{1 / 2} \\
& =2,24 \mathrm{~m} / \mathrm{dt} \\
\mathrm{Q} & =\mathrm{V} \cdot \mathrm{A} \\
& =2,24 \cdot 2 \\
& =4,47 \mathrm{~m}^{3} / \mathrm{dt}
\end{aligned}
$$


Berikut adalah rekapitulasi nilai debit yang mampu ditampung saluran :

Tabel 8. Rekapitulasi nilai debit yang mampu ditampung saluran

\begin{tabular}{|c|c|c|c|c|}
\hline Saluran & $\begin{array}{c}\mathrm{A} \\
\left(\mathrm{m}^{2}\right)\end{array}$ & $\begin{array}{c}\mathrm{V} \\
(\mathrm{m} / \mathrm{det})\end{array}$ & $\begin{array}{c}\mathrm{Q} \\
\text { Saluran } \\
\left(\mathrm{m}^{3} / \text { detik }\right)\end{array}$ & $\begin{array}{c}\text { Bentuk } \\
\text { Saluran }\end{array}$ \\
\hline $1-2$ & 2 & 2,24 & 4,47 & Persegi \\
\hline $2-3$ & 2 & 3,25 & 6,50 & Persegi \\
\hline $3-4$ & 2 & 2,74 & 5,48 & Persegi \\
\hline $4-5$ & 2 & 1,48 & 2,96 & Persegi \\
\hline $5-6$ & 3 & 2,80 & 8,41 & Persegi \\
\hline $6-7$ & 3 & 4,13 & 12,39 & Persegi \\
\hline $7-8$ & 3 & 7,89 & 23,67 & Persegi \\
\hline $8-9$ & 2 & 0,91 & 1,82 & Persegi \\
\hline $9-10$ & 4 & 1,91 & 7,63 & Persegi \\
\hline $10-11$ & 8 & 5,37 & 42,96 & Persegi \\
\hline $11-12$ & 8 & 2,19 & 17,54 & Persegi \\
\hline $12-13$ & 4,8 & 4,10 & 19,70 & Persegi \\
\hline
\end{tabular}

Berikut adalah gambar bentuk saluran drainase di jondul rawang :

\begin{tabular}{|c|c|}
\hline Nama Saluran & Bentuk Saluran \\
\hline Saluran 1 - 2 & $-I L$ \\
\hline Saluran 2 - 3 & $-1 \mathrm{~L}$ \\
\hline Saluran 3-4 & $-1 \stackrel{ }{L}$ \\
\hline Saluran 4 - 5 & 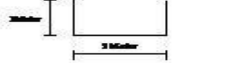 \\
\hline Saluran 5-6 & $-1 L$ \\
\hline Saluran 6 - 7 & -1 \\
\hline
\end{tabular}

Gambar 7a. Profil Melintang Saluran

\begin{tabular}{|c|c|}
\hline Neme Stiven & 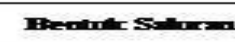 \\
\hline $\sec 3-x$ & $-[\square$ \\
\hline $\operatorname{sen} x-9$ & $-I L$ \\
\hline $\sec 9-10$ & \\
\hline $\operatorname{sen} 20-11$ & - \\
\hline $\sec 11-12$ & - \\
\hline $\sec 12 x-13$ & -1 \\
\hline
\end{tabular}

Gambar 7b. Profil Melintang Saluran

Sketsa tata letak inlet dan karakteristik subcatchment dapat dilihat pada gambar dibawah ini :

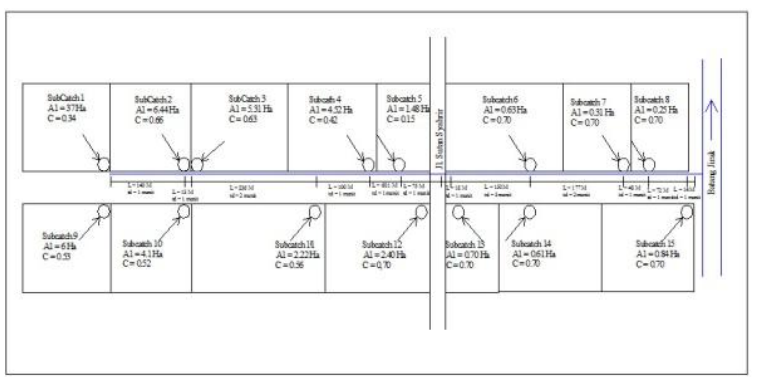

Gambar 8. Sketsa karakteristik subcathment

Perhitungan debit di saluran dapat dilihat pada tabel 9

Tabel 9. Tabel perhitungan debit pada segmen saluran Periode Ulang 5 tahun

\begin{tabular}{|c|c|c|c|c|c|c|c|}
\hline Saluran & tc (Menit) & c & $\begin{array}{c}\mathrm{I} \\
(\mathrm{mm} / \mathrm{jm})\end{array}$ & A (hektar) & $\begin{array}{l}\text { Q Limpasan } \\
\left(\mathrm{m}^{3} / \text { detik }\right)\end{array}$ & $\begin{array}{l}\text { Q Saluran } \\
\left.\text { (m } \mathrm{m}^{3} \text { detik }\right)\end{array}$ & Keterangan \\
\hline 1.2 & 15 & 0,367 & 100,4 & 43,0 & 4,5 & 4,47 & Banjir \\
\hline $2 \cdot 3$ & 16 & 0,414 & 96,2 & 53,5 & 5,92 & 6,50 & Tidak Banijir \\
\hline 3.4 & 17 & 0,432 & 92,4 & 58,9 & 6,53 & 5,48 & Baniji \\
\hline $4-5$ & 19 & 0,437 & 85,8 & 61,1 & 6,36 & 2,96 & Banjir \\
\hline 5.6 & 20 & 0,436 & 82,9 & 65,6 & 6,59 & 8,41 & Tidak Banjir \\
\hline 6.7 & 21 & 0,429 & 80,3 & 67,1 & 6,42 & 12,39 & Tidak Banijir \\
\hline 7.8 & 22 & 0,439 & 77,8 & 69,5 & 6,59 & 23,67 & Tidak Banjir \\
\hline 8.9 & 23 & 0,441 & 75,5 & 70,2 & 6,50 & 1,82 & Banjir \\
\hline $9-10$ & 26 & 0,446 & 69,6 & 71,4 & 6,16 & 7,63 & Tidak Banjir \\
\hline $10-11$ & 28 & 0,447 & 66,2 & 71,7 & 5,90 & 42,96 & Tidak Banjir \\
\hline $11 \cdot 12$ & 29 & 0,448 & 64,7 & 72,0 & 5,80 & 17,54 & Tidak Banjir \\
\hline $12 \cdot 13$ & 30 & 0,451 & 63,3 & 72,8 & 5,77 & 19,70 & Tidak Banjir \\
\hline
\end{tabular}

Hasil perhitungan diatas dapat diringkas secara skematis seperti ditunjukan pada gambar berikut ini :

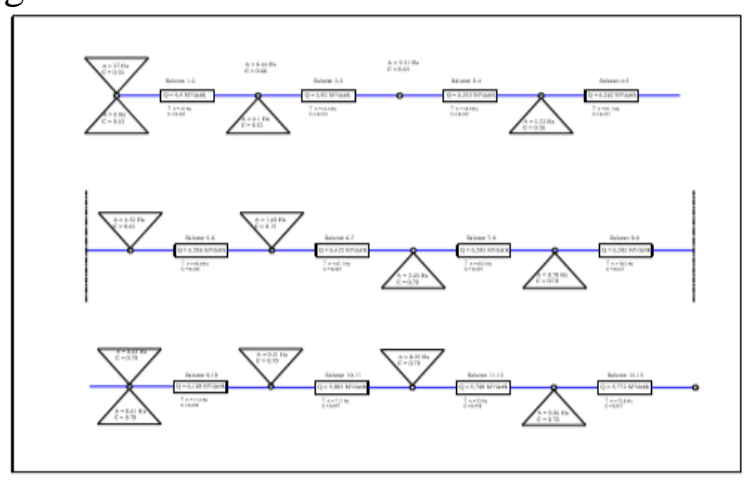

Gambar 8. Perhitungan debit di saluran dengan metode rasional beberapa sub-area

Ada beberapa solusi yang dapat dilakukan untuk mengurangi efek yang 
merugikan akibat limpasan yang tidak terkendalikan. Berikut adalah beberapa solusi efektif mengurangi efek limpasan :

1. Kolam Retensi Kolam retensi adalah kolam yang dibuat untuk menggantikan fungsi lahan resapan yang sudah tidak bisa lagi menjalankan fungsinya dengan maksimal dikarenakan banyak hal. Misalnya saja lahan resapan yang tertutup, lahan resapan yang berfungsi menjadi kawasan perumahan dan perkantoran serta beberapa penyebab lainnya. Kolam buatan ini selanjutnya akan menampung air hujan secara kemudian diresapkan kedalam tanah. Karena berfungsi sebagai resapan buatan, maka kolam retensi dibuat pada bagian yang paling rendah dari lahan. Sedangkan luas dan kedalaman kolam bergantung pada luas lahan yang beralih fungsi menjadi kawasan perkantoran atau pemukiman. Kolam retensi juga berfungsi menjernihkan air sebelum disalurkan ke sebuah waduk. Proses penjernihan air dalam kolam ini lebih murah dan lebih mudah jika dibandingkan dengan penjernihan air dalam waduk karena ukurannya yang lebih kecil. Dengan perencanaan yang baik, kolam ini bisa menjadi tempat yang efektif untuk menampung air hujan sementara waktu dan juga untuk distribusi air.

2. Infiltrasi Permukaan Pengandalian banjir pada saluran tidak hanya dengan memperbesar saluran, akan tetapi adalah bagaimana mengendalikan air dari lahan atau daerah tangkapan air sebelum menuju saluran. Salah satu metode yang dapat mengurangi limpasan yang terjadi di permukaan adalah dengan memperbanyak previous area atau daerah yang mampu infiltrasi. Seperti halaman rumput, lahan parkir, serta membuat sumur resapan. Sumur resapan dianggap cukup efektif untuk mereduksi runoff karena dengan adanya sumur resapan air dapat diserap oleh tanah. Sumur resapan ini harus memperhitungkan besaran muka air tanah.
3. Memperbesar Dimensi Saluran Dengan memperbesar dimensi saluran maka akan memperbesar kapasitas tampungan saluran.

\section{SIMPULAN}

Berdasarkan tujuan penelitian tentang Analisis Banjir di Kawasan Jondul Rawang Kota Padang dapat disimpulkan bahwa :

1. Dari hasil analisa hidrologi pada periode ulang rencana 2 tahun, 5 tahun dan periode 10 tahun diperoleh curah hujan masingmasing adalah 213,18 $\mathrm{mm} / \mathrm{jam}$, $251,62 \mathrm{~mm} / \mathrm{jam}$ dan 274,44 mm/jam.

2. Berdasarkan hujan rencana pada periode ulang rencana 2 tahun, 5 tahun dan 10 tahun tersebut, diperoleh debit paling tinggi terdapat pada subcatchment 1 dengan luas areal $37 \mathrm{Ha}$. Menghasilkan debit manual sebesar 1,92 m3 /dt, 2,15 $\mathrm{m} 3 / \mathrm{dt}$ dan 2,277 m3 /dt, dan debit pada aplikasi EPA SWMM sebesar 4,86 m3 /dt, 6,03 m3 /dt dan 6,75 m3/dt.

3. Untuk mengatasi permasalahan banjir tersebut salah satu metodenya adalah dengan memperbesar dimensi saluran. Karena dapat dilihat pada saluran $8-9$ debit limpasan yang terjadi cukup besar yaitu $6,50 \mathrm{~m} 3 \quad / \mathrm{dt}$ sedangkan daya tampung saluran tersebut hanya 1,82 $\mathrm{m} 3 / \mathrm{dt}$.

\section{SARAN}

Saran yang dapat penulis usulkan :

1. Untuk mengatasi banjir di drainase Jondul Rawang perlu dilakukan perbaikan saluran dengan cara memperbesar dimensi saluran agar mampu menampung debit limpasan yang mengalir saat musim hujan.

2. Perlu dilakukannya perawatan secara berkala dan edukasi tentang pentingnya menjaga kebersihan dan tidak membuang sampah sembarangan, sehingga sampah tidak akan menumpuk di saluran yang mengakibatkan saluran tersumbat. 


\section{DAFTAR PUSTAKA}

[1] [EPA] Environmental Protection Agency. 2015. Storm Water Management Model Version 5.1. with Development (SWMM) Low Impact (LID)controls diaksesmelaluihttp://www.epa.gov/ water-research/storm-watermanagement-model-swmm

[2] Gunadarma. 2011.Hidraulika Pada Saluran Terbuka. Usaha Nasional. Surabaya

[3] Kamiana, I Made. 2011 .Materi Kuliah Drainase dan Pengendalian Banjir. Graha Ilmu. Yogyakarta.

[4] Lingga, Dea Fatonah R. 2017. Evaluasi Sistem Drainase Bandar Purus Menggunakan Software SWMM. [Diploma, Thesis]. Universitas Andalas, diakses melalui http://scholar.unand.ac.id/id/epr int/27085.
[5] Robert J. Kodoatie. 2005.Pengantar Manajemen Infrastruktur. Pustaka Pelajar. Yogyakarta.

[6] Rossman L. 2004. Storm Water Management Model User's Manual Version 5.0. Cincinnati. Washington (US): EPA United Stated Environmental Agency.

[7] Soemarto, 1999.Hidrologi Teknik. Penerbit Erlangga, Jakarta.

[8] Soewarno, 1995.Hidrologi Aplikasi Metode Statistik Untuk Analisa Data. Penerbit Nova, Bandung.

[9] Suripin. 2004 .Perencanaan Sistem Drainase yang Berkelanjutan. Yogyakarta: Andi Offset.Triatmodjo B. 2008. Hidrologi Terapan.Yogyakarta (ID): Beta Offset.

[10] Wesli. 2008. Drainase Perkotaan. Yogyakarta: Graha Ilmu. 